\title{
THE INFLUENCE OF ISLAMIC ENTREPRENEURSHIP TOWARDS THE ORGANIZATION PERFORMANCE THROUGH ORGANIZATION COMMITMENT IN MA'SOEM GROUP
}

\author{
Yudhy \\ Universitas Ma'soem \\ J1. Raya Cipacing No.22, Cipacing, Kec. Jatinangor, Bandung Timur, Jawa Barat \\ 45363 \\ yudhy.amik@gmail.com
}

\begin{abstract}
The purpose of this research is to discuss the influence of Islamic entrepreneurship towards the organization performance through organization commitment. The object of this research is the unit leader and division leader in Ma'soem Group. The appropriate sample used has been randomly chosen by probability sampling method with 118 respondents. Data analysis is conducted using Structural Equation Modeling (SEM). The result of research shows that Islamic entrepreneurship is affecting the organization performance, and the organization commitment do not affect the organization performance. For indirect influence, organization commitment cannot mediate the influence of Islamic entrepreneurship towards organization performance.
\end{abstract}

Keywords: Islamic entrepreneurship, organizational commitment, organizational performance

\section{Introduction}

Entrepreneurship has been a specific interest for researchers who focused on business development and public policy planning. This is because entrepreneurship encourage market innovation which is very important in the more complex global business (Ratten, 2014). The willingness of businessmen to face the risk and be creative is the main characteristics of their behaviors and personalities. Entrepreneurship enables people to participate in the development of economic and regional by encouraging the job growth and new business activities (Ramadani et al., 2015).
Islam is one of the religions that encourage its followers to be an entrepreneur (Faizal et al., 2013). In Islam, there is no separation between entrepreneurship activity and religion. Islam has its own entrepreneurship characteristics and guideline principles based on Al-Qur'an and Hadith to guide the entrepreneurship operation (Oukil, 2013). So that in its development, emerges the term Islamic entrepreneurship as a model identity of entrepreneurship with Islamic characteristics or principles. Islamic entrepreneurship has become a distinctive attraction since this concept emerge in the middle of domination of Indonesian citizens which is majority Muslims. 
Yudhy, The Influence Of Islamic Entrepreneurship Towards The Organization Performance Through ..

Islamic entrepreneurship spirit is not only applied to those independent entrepreneurs, but also can be applied to those who works in a company. So that their actions and ethics in working are based on Islamic entrepreneurship values. Especially for those who are leaders of a company where they have the authority to manage and lead a lot of people. Islamic entrepreneurship will encourage the action of a manager in determining the mission and vision of the company. Musfialdy \& Soim (2016) in their study have found that Islamic values are able to improve the performance in micro business in Pekanbaru. This shows that Islam is not only concerns about the afterlife matter but also pay attention to the current life on earth. Islamic values like aqidah, worship activity, and muamalah can encourage Muslims to work hard and be patient.

Islamic entrepreneurship values can also encourage the organization commitment to drive the company together with all the organization member. One of the most important needs of the staffs or employees in an organization is to build trust between the managers and them so that it formed the organization commitment. Managing the organization commitment through building the trust will all engaged parties will run towards the organization effectivity and can reduce cost of monitoring and evaluation.
Therefore, in the end, organization commitment can accelerate the increase of organization performance to be better (Kashefi et al., 2013).

Organization style that applies Islamic entrepreneurship is seen in Ma'soem Group. Ma'soem Group itself has established since 1973 dan has developed to become a big corporation in West Java area. As for the corporate exists under the Ma'soem Group among others are: Ma'soem Gas Station, AlMa'soem Drinking Water, Almasoem Sharia Rural Banks, PT Sampurna Gas Bandung, Al-Ma'soem Pharmacy, PT Arias Mas, PT Ma'soem Arias, and Al Ma'soem Khadimul Hajj. Besides that, Ma'soem Group also engages in the education field through Al-Ma'soem Foundation, with Islamic education ranged from kindergarten to college.

Based on the exposure above, it is interesting to review further regarding the influence of Islamic entrepreneurship towards organization performance through organization commitment in Ma'soem Group.

\section{Discussion}

\section{Islamic Entrepreneurship}

Entrepreneurship is a process for an individual who strives to chase the opportunity without pay attention to the resources they currently controlled for the 
sake of exploiting the goods and services in the future (Barringer \& Ireland, 2016). In searching those opportunities, sometimes they explore unknown things to find new horizon and reveal new opportunity for the benefit of humankind. Such active search may involve risk taking and also need innovative thinking (Faizal et al., 2013).

Islam is the complete way of life and entrepreneurship is a part of its system. Islamic entrepreneurship is the system, process, and practice of running a business in Islamic way (Razak, 2017). Islam as the way of life called Al-Dien including all the spectrum of activities needed by Muslims to run their life in this world. Islam, through Al-Qur'an and As-Sunnah, provides concrete guideline for all Muslims including the activity and practice of entrepreneurship. For Muslim entrepreneur, success is not only determined by material rewards, even though business success is an inseparable part, but also in the form of social-economic and metaphysics achievement - in this world and in the afterlife (Razak, 2017). This achievement is called Al-Falah, which shows the state of welfare of material and spiritual.

\section{Organization Commitment}

According to Robbins \& Timothy (2013), organization commitment is the stage where the employees recognize a certain group with certain objectives also wish to keep the status as the member of the group. While Luthans (2010) defines organization commitment into 3 (three) matters; (1) strong willingness to be a member of a certain group; (2) willingness to work hard as the organization aspiration; (3) certain willingness to accept the value and objectives of the organization.

Employees with high level of commitment towards the organization see themselves as an integral part of the organization. Anything that threatens the organization is also a danger to them. Such employee becomes creatively involved in the organization mission and values, and continue to think of ways to do their job better. Bottom line is, employee who has commitment to work for the organization is as if that organization is belong to them (Irefin \& Mechanic, 2014).

In other words, this is the behavior that reflects the loyalty of the employee towards the organization and the next stage is where the member of the organization express concerns towards the organization, the success, and further developments. So organization commitment is expected to be able to improve organization performance.

\section{Organization Performance}

According to Tomal \& Jones (2015), organization performance is the actual result or outcome from an organization measured towards the desirable output of the 
Yudhy, The Influence Of Islamic Entrepreneurship Towards The Organization Performance Through ..

organization. Kaplan \& Norton (1992) states that organization performance as a set of financial and non-financial indicators that able to assess the level of achieved goals and objectives of the organization.

\section{Research Object}

This research is conducted to the unit leader and division leader in Ma'soem Group. Sample taken as research data randomly selected according to the probability sampling method with 125 respondents who are unit leader and division leader in Ma'soem Group. Ma'soem Group is chosen as the research object based on the company style which is thick with its Islamic nuances. As known that Ma'soem Group has unit of education foundation that includes early education to college which based on Islam. Aside from that, the development of business of Ma'soem Group is rather fast until now that exists in its second generation.

\section{Research Method}

This research uses quantitative approach that tested the influence of Islamic entrepreneurship towards organization commitment, and its implication towards organization performance. Data used is primary data which obtained from the respondents through questionnaire. The questionnaire consists of questions related to research variable with measurement scale of 5 (five) point Likert Scale.

Below is the figure of research model to see the relationship pattern of this research:

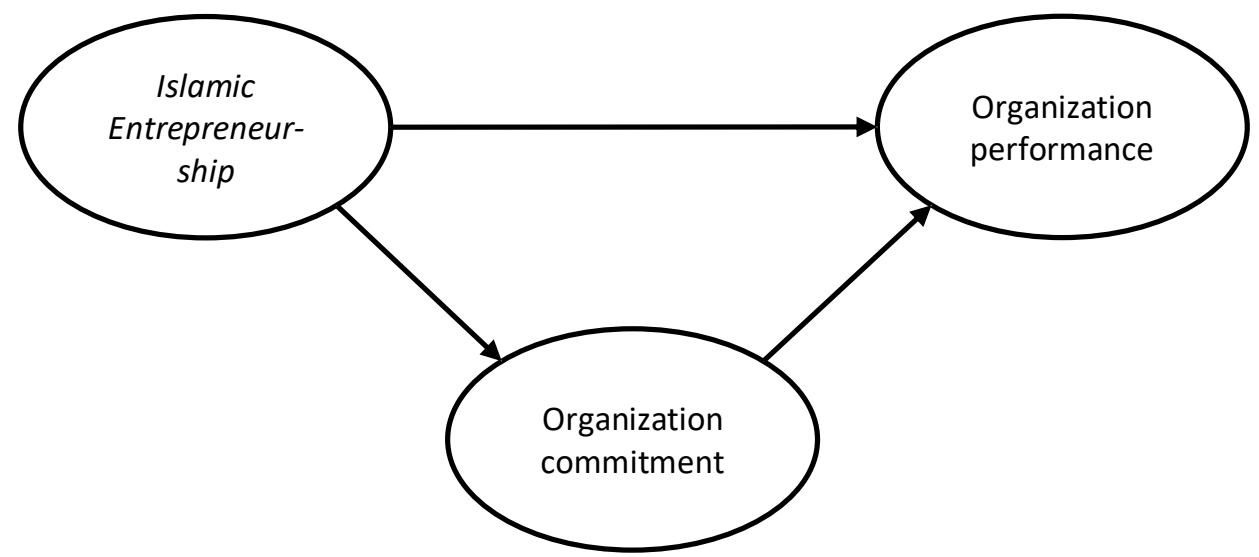

Gambar 1.

Research Model

Based on the questionnaire distributed to 125 respondents, obtained 125 filled questionnaires, but only 118 that are feasible to be used as sample and processed further.
In processing and analyzing the research data, researcher refer to Setiawan \& Mauluddi (2019) also (Setiawan et al., 2020). 


\section{Measurement Model}

To determine the best indicator as individual construct, the analysis of exploration factor is conducted to ensure the number of indicators which will be maintained for each of the three laten variables included in this research; Islamic entrepreneurship (IE), organization commitment (CT), and organization performance (PM); this shows in Table 1 below.
Refer to Setiawan \& Mauluddi (2019), early stage of measurement conducted is looking at the validity and reliability of the questionnaire instrument using Outer Loadings, Average Variance Extracted (AVE), Cronbach's Alpha and Composite Reliability (CR). The number of result tested indicator from data gathering is Islamic entrepreneurship by 14 items, organization commitment by 10 items, and organization performance by 21 items.

Table 1.

Loading of The Item Measurement, Cronbach's Alpha, Composite Reliability (CR) and AVE

\begin{tabular}{lcccccc}
\hline \multicolumn{1}{c}{ Konstruk } & $\begin{array}{c}\text { Jumlah } \\
\text { Indikator } \\
\text { Layak }\end{array}$ & Loading & AVE & $\begin{array}{r}\text { Cronbac } \\
\text { h's Alpha }\end{array}$ & CR & Status \\
& & & & & & \\
\hline $\begin{array}{l}\text { Islamic } \\
\text { Entrepreneurshi }\end{array}$ & 8 & $0.805-$ & 0.765 & 0.956 & 0.963 & Reliabel \\
$\mathrm{p}$ & & 0.944 & & & & \\
\hline $\begin{array}{l}\text { Organizational } \\
\text { commitment }\end{array}$ & 10 & $0.565-$ & 0.502 & 0.889 & 0.909 & Valid dan \\
& & 0.776 & & & & Reliabel \\
\hline $\begin{array}{l}\text { Organizational } \\
\text { performance }\end{array}$ & 14 & $0.883-$ & 0.867 & 0.988 & 0.989 & Valid dan \\
\hline
\end{tabular}

Source: Data processed (2020)

From the test result of Table 1 above, it can be known that Outer Loadings for all indicators shows number above 0.5 so they pass to become the indicator on such laten variables (Setiawan \& Mauluddi, 2019). For the AVE value in all variables is above 0.5 which means that it is a measure of the amount of variance that can be captured by the construct compared to variance that caused by measurement error (Setiawan \& 
Yudhy, The Influence Of Islamic Entrepreneurship Towards The Organization Performance Through ..

Mauluddi, 2019). As for the value of Cronbach's Alpha in all variable is above 0.7, the same goes with $\mathrm{CR}$ value which is above 0.7 which means that it shows the consistency value from each indicator in measure its construct (Setiawan \& Mauluddi, 2019). Based on all tests above it can be concluded that all variables are valid and reliable and feasible to be continued in the next stage of testing.

\section{Structural Model}

In measuring the geometrical mean from the equation use the Goodness of Fit (GoF) (Setiawan \& Mauluddi, 2019). Also look at the $\mathrm{R}^{2}$ value to assess how good the predictor is in this research model.

Table 2.

\section{Goodness of Fit (GoF) Index}

\begin{tabular}{lll}
\hline Variable & AVE & $\boldsymbol{R}^{2}$ \\
\hline Islamic & 0.765 & \\
Entrepreneurship & & \\
Organization & 0.502 & \\
commitment & & 0.050 \\
Organization & 0.867 & \\
performance & & 0.901 \\
Average score & 0.711 & 0.476 \\
AVE x $R^{2}$ & & 0.338 \\
GoF $=\sqrt{ }\left(\mathrm{AVE} \times R^{2}\right)$ & & 0.582 \\
\hline
\end{tabular}

Source: Data processed (2020)

In the table 2 above, the value of GoF shows 0.582 which means that the proposed relationship model classified as large, this shows that such model performs relatively well (Setiawan \& Mauluddi, 2019). Classification of GoF value is small for 0.2 , medium for 0.25 , and large for 0.36 (Hair, et al., (2017) in Setiawan \& Mauluddi (2019).

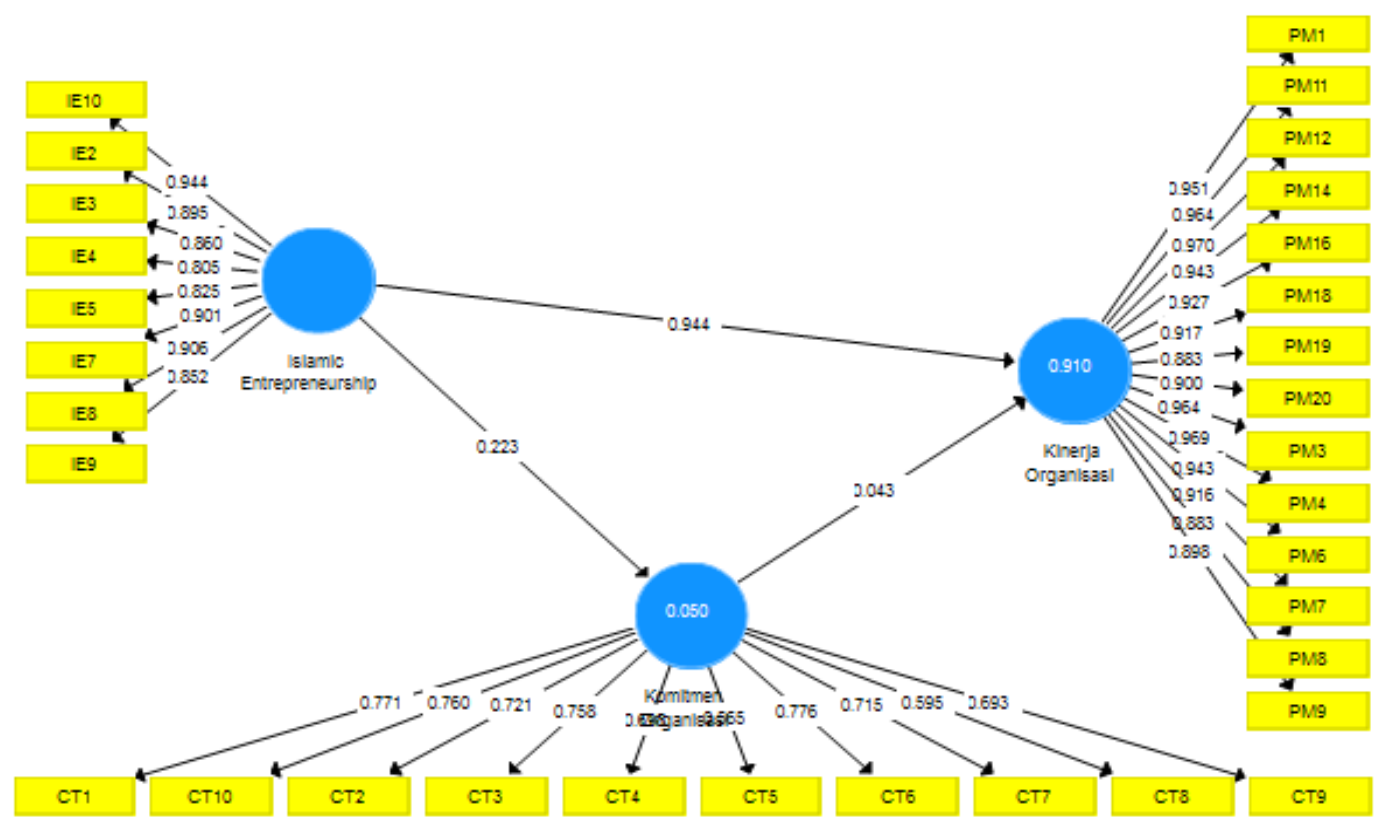

Figure 2. 


\section{Model Testing Result}

The $\mathrm{R}^{2}$ value for organization commitment is 0.050 or about 5 percent, which means that the studied independent variables can explain 5 percent organization commitment. While the $\mathrm{R}^{2}$ value for organization performance is 0.901 or about 90.1 percent, which means that the studied independent variables can explain 90.1 percent organization performance. The $\mathrm{R}^{2}$ for organization performance is very high, close to 1 . Other than to see how big is the influence, $\mathrm{R}^{2}$ can also be use as a good predictor tool for a model (Setiawan \& Mauluddi, 2019).

Table 3.

Path Coefficient

\begin{tabular}{lccc}
\hline \multicolumn{1}{c}{ Path } & $\begin{array}{c}\text { Coefficien } \\
\text { t }\end{array}$ & t-Stat & $\begin{array}{c}\text { P } \\
\text { Values }\end{array}$ \\
\hline $\begin{array}{l}\text { Islamic Entrepreneurship => Organization } \\
\text { commitment }\end{array}$ & 0.223 & 2.717 & $0.000^{*}$ \\
$\begin{array}{l}\text { Islamic Entrepreneurship }=>\text { Organization } \\
\text { performance }\end{array}$ & 0.944 & 59.384 & $0.000^{*}$ \\
$\begin{array}{l}\text { Komitmen Organisasi => Organization performance } \\
\begin{array}{l}\text { Islamic Entrepreneurship => Organization } \\
\text { commitment => Organization performance }\end{array}\end{array}$ & 0.043 & 1.159 & 0.247 \\
\hline$*$ Significant at the 5\% level & 0.010 & 0.944 & 0.346 \\
\hline
\end{tabular}

Source:Data processed (2020)

Table 3 shows the relationship each variable. The test result states that: (i) Islamic entrepreneurship affecting towards organization commitment with coefficient 0.223 which significant in $\mathrm{p}$-value $<0.05$ or $5 \%$; (ii) Islamic entrepreneurship affecting towards organization performance with coefficient 0.944 which significant in $\mathrm{p}$ value $<0.05$ or $5 \%$; (iii) organization commitment does not affect towards organization performance due to p-value $>0.05$ or $5 \%$; also Islamic entrepreneurship does not affect towards organization performance through organization commitment due to $\mathrm{p}$-value $>0.05$ or $5 \%$.

\section{Research Result Discussion}

Based on the result of data processing it can be known that Islamic entrepreneurship values owned by leaders of Ma'soem Group significantly affecting towards organization commitment. As long as Ma'soem Group engages in the corridor that does not against Islamic values, then the individuals having the Islamic entrepreneurship spirit will move harmoniously with the organization values and objectives. Furthermore, if this Islamic entrepreneurship is owned by all leaders, it will create a strong organizational bond and can bring the organization 
Yudhy, The Influence Of Islamic Entrepreneurship Towards The Organization Performance Through ..

objective towards a better way. the bond created in Ma'soem Group is not only formal bond in the workplace, but also spiritual bond. Since the objective of Muslim businessmen not only tied to material matters, but beyond covering social-economic and metaphysics achievement (Razak, 2017). Thus, the essence of organization commitment stated by Luthans (2010) can be true: (1) strong willingness to be a member of a certain group; (2) willingness to work hard as the organization aspiration; (3) certain willingness to accept the value and objectives of the organization. Therefore, it can be said that all the elements, either leaders or employees in Ma'soem Group have a strong sense of ownership towards the organization even willing to give something more than they should through working hard. Such matter can strengthen the organization commitment in Ma'soem Group.

Aside from that, the result of this research also found that Islamic entrepreneurship affects towards organization performance in Ma'soem Group. The influence resulted by Islamic entrepreneurship values towards organization performance is very big. According Musfialdy \& Soim (2016), Islamic values in entrepreneurship such as hard-worker, resilient and patient is an encouragement to the increase of business productivity thus enabling the achievement of greater profits. In the organization can be explained that the leader who has Islamic entrepreneurship spirit has a strong determination to drive the organization to achieve organization objective, in this matter Ma'soem Group. Thus, it can be seen in the high increase of Ma'soem Group performance.

\section{Conclusions}

Disederhanakan menjadi: From result and discussion above, it can be concluded that (i) Islamic entrepreneurship affecting towards organization commitment; (ii) Islamic entrepreneurship affecting towards organization performance; (iii) organization commitment does not affect towards organization performance; also, Islamic entrepreneurship does not affect towards organization performance through organization commitment.

With the conclusion above, Ma'soem Group management especially and other companies in general may consider Islamic entrepreneurship as a solution to drive the company to have good performance. Islamic entrepreneurship spirit not only owned by the business owner, but also it has to be owned by leaders and employees. This can be done through intensive training. 


\section{Reference}

Barringer, B. R., \& Ireland, R. D. (2016). Entrepreneurship. Peason.

Faizal, P. R. M., Ridhwan, A. A. M., \& Kalsom, A. W. (2013). The Entrepreneurs Characteristic from al-Quran and al-Hadis. International Journal of Trade, Economics and Finance, 4(4), 191-196. https://doi.org/10.7763/IJTEF.2013.V4.284 Irefin, P., \& Mechanic, M. A. (2014). Effect of Employee Commitment on Organizational Performance in Coca Cola Nigeria Limited Maiduguri, Borno State. IOSR Journal Of Humanities And Social Science, 19(3), 33-41.

Kaplan, R. S., \& Norton, D. P. (1992). The balanced scorecard - measures that drive performance. Harvard Business Review, $71-79$

Kashefi, M. A., Adel, R. M., Abad, H. R. G., Aliklayeh, M. B. H., Moghaddam, H. K., \& Nadimi, G. (2013). Organizational commitment and its effects on organizational performance.

Interdisciplinary Journal of Contemporary Research in Business, 4(12), 501-510.

Luthans, F. (2010). Organizational Behavior (12th ed.). McGraw-Hill Education.
Musfialdy, \& Soim, M. (2016). Peranan Nilai-Nilai Islam dalam Meningkatkan Kewirausahaan dan Kinerja Usaha Mikro (Studi di Kota Pekanbaru Provinsi Riau). Kutubkhanah: Jurnal Penelitian Sosial Keagamaan, 19(1), 80-93.

Oukil, M. S. (2013). Entrepreneurship and entrepreneurs in an islamic context. Journal of Islamic and Human Advanced Research, 3(3), 111-131.

Ramadani, V., Dana, L.-Paul., Ratten, V., \& Tahiri, S. (2015). The context of Islamic entrepreneurship and business: Concept, principles and perspectives. International Journal Business and Globalisation, 15(3), 244-261.

Ratten, V. (2014). Entrepreneurship in developing regions. International Journal of Entrepreneurship and Small Business, 22(2), 135-137.

Razak, K. A. (2017). Islamic Entrepreneurship Model. Internasional Muamalat and Entrepreneurship Conference (IMEC 4).

Robbins, S. P., \& Timothy, A. (2013). Organizational behavior (15th ed.). Prentice Hall.

Setiawan, S., \& Mauluddi, H. A. (2019). Perilaku Konsumen dalam Membeli Produk Halal di Kota Bandung. At-Tijaroh: Jurnal 
Yudhy, The Influence Of Islamic Entrepreneurship Towards The Organization Performance Through ..

Ilmu Manajemen Dan Bisnis Islam, 5(2), $232-246$.

Setiawan, S., Setyowati, D. H., \& Tripuspitorini, F. A. (2020). Dimensi Risiko bagi Konsumen dalam Membeli Produk Halal. Amwaluna: Jurnal Ekonomi Dan Keuangan Syariah, 4(1). https://doi.org/10.29313/amwaluna.v4i1.52 20

Tomal, D. R., \& Jones, K. J. (2015). A comparison of core competencies of women and men leaders in the manufacturing industry. The Coastal Business Journal, 14(1), 13-25. 